\title{
PENGARUH PENGGUNAAN BUBUK JAHE MERAH (Zingiber officinale var. Rubrum) TERHADAP SIFAT ORGANOLEPTIK BAKSO DAGING KAMBING
}

\author{
Afikra Armansyah, Friets S. Ratulangi*, Godlief D.G. Rembet
}

Fakultas Peternakan Universitas Sam Ratulangi Manado, 95115

\begin{abstract}
ABSTRAK
Tujuan penelitian ini untuk mengetahui pengaruh penggunaan bubuk jahe merah terhadap sifat organoleptik bakso daging kambing. Materi yang digunakan yaitu daging kambing jantan segar bagian paha belakang, tepung tapioka, garam, penyedap rasa, bawang putih, merica, bubuk jahe merah, es batu serta peralatan pengolahan. Percobaan ini menggunakan rancangan acak lengkap lima perlakuan dengan menggunakan 30 ulangan. Perlakuan adalah R0 daging $300 \mathrm{~g}$ ditambah bubuk jahe merah $0 \mathrm{~g}, \mathrm{R} 1$ daging $300 \mathrm{~g}$ ditambah bubuk jahe merah 1,5 g, R2 daging $300 \mathrm{~g}$ ditambah bubuk jahe merah 3 g, R3 daging $300 \mathrm{~g}$ ditambah bubuk jahe merah 4,5 g dan R4 daging $300 \mathrm{~g}$ ditambah bubuk jahe merah $6 \mathrm{~g}$. Pengujian organoleptik yang dilakukan yakni uji mutu hedonik yang terdiri dari variabel-variabel warna, aroma, rasa dan kekenyalan. Untuk menentukan perbedaan perlakuan dilakukan dengan uji Tukey (HSD). Hasil penelitian menunjukkan bahwa perlakuan memberikan pengaruh nyata $\quad(\mathrm{P}<0,05)$ terhadap aroma dan rasa, sedangkan untuk variabel warna dan kekenyalan perlakuan tidak memberikan pengaruh nyata $(\mathrm{P}>0,05)$. Penggunaan bubuk jahe merah level $3 \mathrm{~g}$ dapat memberikan tingkat penerimaan terhadap sifat organoleptik bakso daging kambing.
\end{abstract}

Kata kunci: Daging kambing, jahe merah, bakso

*Korespondensi (corresponding Author) Email: fsratulangi@ymail.com

\section{ABSTRACT}

THE UTILIZATION OF RED GINGER POWDER (Zingiber officinale var. Rubrum) ON ORGANOLEPTIC CHARACTERISTIC OF MUTTON MEATBALLS. This study was conducted to evaluate the utilization of red ginger powder on the organoleptic characteristic of mutton meatballs. The materials used were fresh mutton meat on the hamstrings, tapioca flour, salt, flavoring, garlic, pepper, red ginger powder, ice cubes and processing equipment tools. The experimental design used in this study was a Completely Randomized Design of five treatments with 30 replications. The treatment was $300 \mathrm{~g}$ of meat and $0 \mathrm{~g}$ red ginger powder (R0), $300 \mathrm{~g}$ of meat and 1.5 $\mathrm{g}$ red ginger powder (R1), $300 \mathrm{~g}$ of meat and $3.0 \mathrm{~g}$ red ginger powder (R2), $300 \mathrm{~g}$ of meat and $4.5 \mathrm{~g}$ red ginger powder (R3), and $300 \mathrm{~g}$ of meat and $6 \mathrm{~g}$ red ginger powder (R4). Organoleptic testing performed was using the hedonic quality test. The variables measured consisted of color, flavor, taste and elasticity of meatballs. Determination of the average difference among treatments was done by Tukey (HSD) test. The results showed that the treatments affected significantly on flavor and taste. However, treatments did not affect significantly on color and elasticity of meatballs. The use of $3 \mathrm{~g}$ red ginger powder could provide acceptance levels on organoleptic characteristic of mutton meatballs.

Keywords: Mutton meat, red ginger, Meatballs 


\section{PENDAHULUAN}

Daging kambing merupakan salah satu bahan pangan hewani yang memiliki peran penting untuk memenuhi kebutuhan gizi manusia. Namun daging kambing memiliki bau khas atau bau tidak sedap yang kurang disukai, sehingga daging kambing membutuhkan pengolahan diantaranya untuk memberikan cita rasa yang berbeda, memperpanjang masa simpan dan penganekaragaman produk olahan daging kambing misalnya bakso.

Bakso merupakan salah satu produk olahan hasil ternak yang bergizi dan digemari masyarakat. Produk olahan bakso pada umumya menggunakan bahan baku utama daging dan bahan tambahan lainnya seperti tepung tapioka, garam, bawang putih, merica, bumbu-bumbu, penyedap rasa dan es batu. Daging yang biasanya dipakai adalah daging sapi, ayam dan ikan sedangkan tepung yang biasanya dipakai yaitu tepung tapioka (Kusnadi et al., 2012). Bakso yang menggunakan daging sapi, ikan maupun ayam sudah banyak dan mudah ditemukan seperti di restoran, rumah makan maupun warung pinggiran, namun bakso daging kambing tidak terkenal karena bau khas daging kambing. Aroma daging kambing bisa dilawan dengan penambahan bumbu rempah yang banyak, misalnya jahe.
Jahe (Zingiber officinale) merupakan tumbuhan yang rimpangnya banyak digunakan sebagai rempah dalam pembuatan makanan maupun minuman. Banyak masyarakat yang menyukai aroma khas pada jahe, namum jahe juga dapat memberikan sensasi rasa pedas dan hangat. Aroma pada jahe disebabkan oleh minyak atsiri, kandungan oleoresin yang terdiri dari gingerol dan shogaol menyebabkan rasa pedas sedangkan senyawa turunan terpenoid pada jahe seperti seskuiterpen zingiberene juga memberikan kontribusi sensori rasa hangat. Ada tiga jenis jahe yang dikenal, yaitu jahe besar, jahe kecil dan jahe merah. Jahe merah mempunyai banyak keunggulan dibandingkan dengan jenis lainnya terutama jika ditinjau dari segi kandungan senyawa kimia dalam rimpangnya (Panjaitan et al., 2012).

Sifat organoleptik adalah sifat mutu produk yang dapat diukur atau dinilai dengan uji atau penilaian organoleptik. Kadang-kadang juga disebut sifat sensorik karena penilaiannya berdasarkan rangsangan sensorik pada organ indra. Palatabilitas panelis dapat ditunjukkan melalui uji organoleptik yang meliputi warna, aroma, rasa dan kekenyalan. Uji ini dengan metode hedonik dan mutu hedonik. Pengujian hedonik dilakukan untuk melihat kesukaan panelis tanpa membandingkan satu sama lain sedangkan uji mutu hedonik tidak menyatakan suka atau tidak suka 
melainkan menyatakan kesan tentang baik atau buruk, ini disebut kesan mutu hedonik. Uji mutu hedonik yaitu uji kualitas yang dimulai dengan skala 1 hingga skala 5 sesuai variabel yang diamati (Soekarto, 1985). Rasa, bau dan kekenyalan merupakan faktor- foktor yang perlu mendapat perhatian dalam pembuatan bakso.

\section{MATERI DAN METODE PENELITIAN}

\section{Lokasi dan Waktu Penelitian}

Penelitian ini dilaksanakan di Laboratorium Teknologi Hasil Ternak, Fakultas Peternakan Universitas Sam Ratulangi Manado sejak tanggal 7 sampai 20 Desember 2016.

\section{Materi Penelitian}

Bahan. Bahan yang digunakan untuk pembuatan bakso yaitu daging kambing jantan segar berumur kurang lebih 1,5 tahun dari bagian paha belakang (gandik) sebanyak $1500 \mathrm{~g}$ dipisahkan dengan ditimbang masing-masing 300 g menjadi 5 perlakuan. Bahan tambahan yaitu, tepung tapioka, garam, penyedap rasa, bawang putih, merica, bubuk jahe merah serta es batu. Bahan untuk uji organoleptik yaitu, air mineral dan ketimun.

Alat. Alat yang digunakan dalam pembuatan bakso adalah penggiling daging, Chopper, timbangan dan peralatan pengolahan lain. Peralatan yang digunakan untuk uji organoleptik bakso adalah piring, sendok, gelas, tusuk gigi, kertas tisu, kertas kuisioner dan alat tulis.

\section{Pembuatan bubuk jahe merah}

Jahe merah segar dengan berat $700 \mathrm{~g}$ dicuci bersih, setelah itu rimpang jahe dipotong kecil-kecil lalu dijemur dibawah sinar matahari sampai benar-benar kering. Kemudian jahe kering di blender hingga halus, setelah itu diayak dengan ayakan nomor 60 dilanjutkan dengan ayakan nomor 80. Rimpang jahe dengan berat 700 g menghasilkan $350 \mathrm{~g}$ bubuk jahe. Diagram alir pembuatan bubuk jahe merah dapat dilihat pada Gambar 1.

Pembuatan bakso (Tiven et al., 2007)

Daging kambing segar yang telah dibersihkan dipotong kecil-kecil. Kemudian daging dengan berat $1500 \mathrm{~g}$ dipisahkan dengan ditimbang masingmasing 300 g menjadi 5 perlakuan, setelah itu daging 


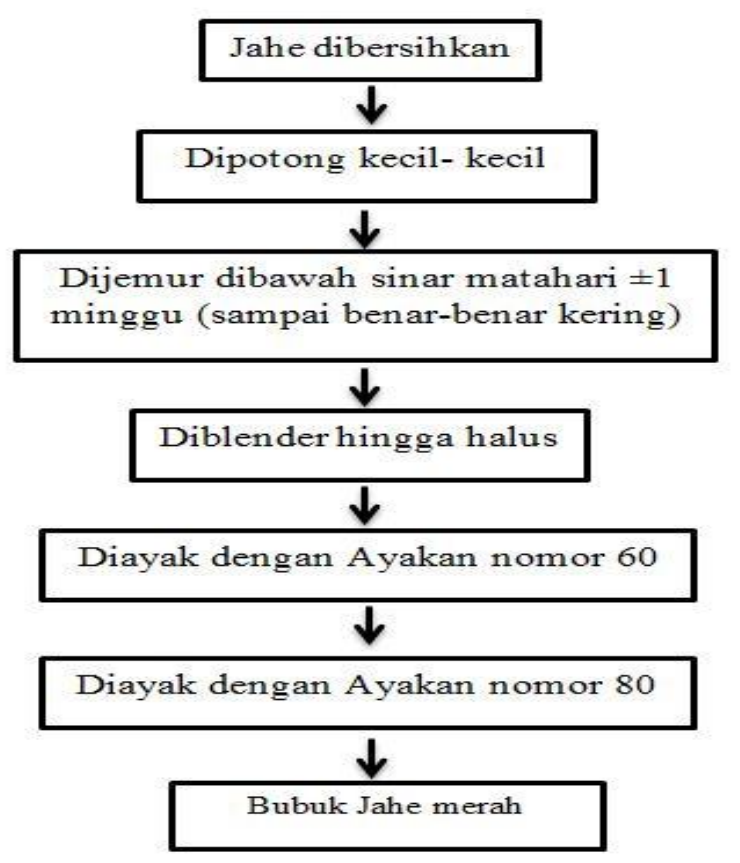

Gambar 1. Diagram alir pembuatan bubuk jahe merah

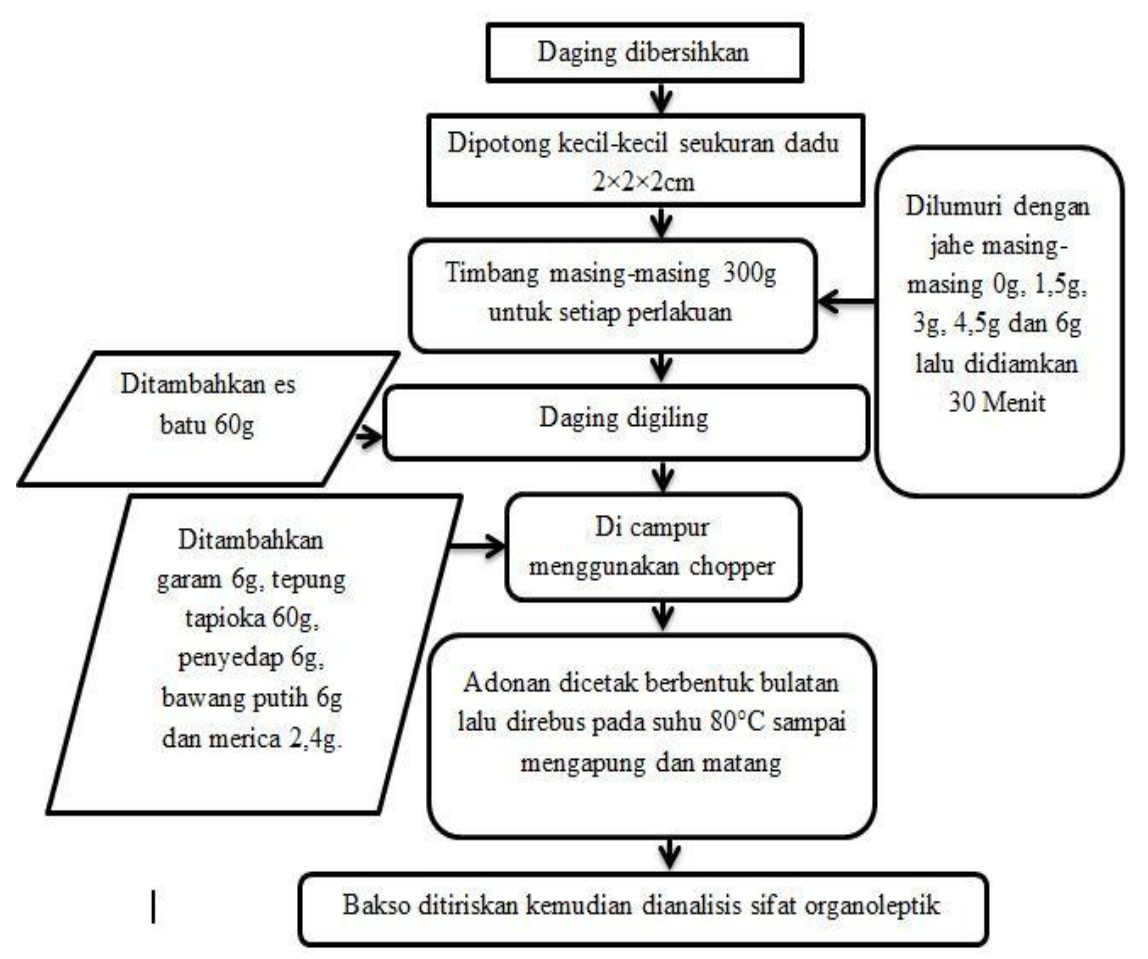

Gambar 2. Diagram alir pembuatan bakso 
dilumuri bubuk jahe merah dengan level 0 $\mathrm{g}, 1,5 \mathrm{~g}, 3 \mathrm{~g}, 4,5 \mathrm{~g}$ dan $6 \mathrm{~g}$ pada tiap perlakuan selama 30 menit. Lalu setiap perlakuan digiling menggunakan penggiling daging dengan menambahkan es batu $60 \mathrm{~g}$. Tahap berikutnya dimasukkan ke dalam chopper dengan menambahkan garam $6 \mathrm{~g}$, penyedap rasa $6 \mathrm{~g}$, tepung tapioka $60 \mathrm{~g}$, bawang putih $6 \mathrm{~g}$ dan merica 2,4g. Adonan dibuat bulatan kemudian direbus pada suhu $80^{\circ} \mathrm{C}$ hingga bakso terapung dan matang. Diagram alir pembuatan bakso dapat dilihat pada Gambar 2.

\section{Rancangan penelitian dan analisis data.}

Rancangan percobaan yang digunakan dalam penelitian ini adalah rancangan acak lengkap lima perlakuan (Steel dan Torrie 1993). Dengan menggunakan 30 panelis sebagai ulangan (Soekarto, 1985). Perlakuan adalah sebagai berikut :

R0 : Daging kambing $300 \mathrm{~g}+$ bubuk jahe merah $0 \mathrm{~g}$

R1 : Daging kambing $300 \mathrm{~g}+$ bubuk jahe merah $1,5 \mathrm{~g}$

R2 : Daging kambing $300 \mathrm{~g}+$ bubuk jahe merah $3 \mathrm{~g}$
R3 : Daging kambing $300 \mathrm{~g}+$ bubuk jahe merah $4,5 \mathrm{~g}$

R4 : Daging kambing $300 \mathrm{~g}+$ bubuk jahe merah $6 \mathrm{~g}$

Data yang diperoleh dari hasil uji organoleptik kemudian ditabulasi dan dianalisis menggunakan analisis ragam (Analisys of Variance) dengan bantuan aplikasi komputer SPSS (Statistical Package for the Sosial Sciences) versi 20. Perlakuan yang berbeda nyata diuji lanjut dengan Tukey (HSD).

\section{Variabel yang diukur}

Penilaian uji mutu hedonik yaitu uji kualitas bakso berdasarkan pengamatan panelis yang dimulai dengan skala 1 hingga skala 5 sesuai variabel yang diamati (Soekarto, 1985). Skala mutu hedonik yang digunakan adalah sebagai berikut: Warna skor (1) sangat tidak menarik, (2) tidak menarik, (3) agak menarik, (4) menarik, (5) sangat menarik. Aroma skor (1) sangat tidak sedap, (2) tidak sedap, (3) agak sedap, (4) sedap, (5) sangat sedap. Rasa skor (1) sangat tidak enak, (2) tidak enak, (3) agak enak, (4) enak, (5) sangat enak. Kekenyalan skor (1) sangat tidak kenyal, (2) tidak kenyal, (3) agak kenyal, (4) kenyal, (5) sangat kenyal. 


\section{HASIL DAN PEMBAHASAN}

Berdasarkan hasil penelitian pengaruh penggunaan bubuk jahe merah terhadap sifat organoleptik bakso daging kambing, rataan hasil uji organoleptik bakso dapat dilihat pada Tabel 1.

\section{Warna}

Rataan hasil uji organoleptik bakso daging kambing terhadap warna bakso pada Tabel 1 menunjukkan bahwa penilaian panelis berkisar antara 3,30 sampai 3,57 (agak menarik). Dapat dilihat ada peningkatan penilaian panelis dari $0 \mathrm{~g}$ sampai ke 3 g kemudian menurun kembali dari 4,5 g sampai ke $6 \mathrm{~g}$.

Analisis ragam menunjukkan bahwa penggunaan bubuk jahe merah tidak berbeda $(\mathrm{P}>0,05)$ terhadap warna pada bakso daging kambing. Hal ini diduga bubuk jahe merah yang digunakan pada bakso sampai dengan taraf level 6 g tidak cukup banyak untuk mempengaruhi warna bakso. Menurut Muchtadi dan Sugiono (1992), kandungan enzim proteolitik dalam jahe berpengaruh terhadap perubahan warna daging. Faktor lain yang mempengaruhi warna daging adalah spesies ternak. Selanjutnya dinyatakan bahwa penentu utama warna daging adalah konsentrasi mioglobin dan hemoglobin, kemudian juga disebabkan oleh reaksi pencoklatan non enzimatis antara protein daging yang mengandung asam-asam amino dengan gula pereduksi (Tiven et al., 2007).

Tabel 1. Rataan hasil uji organoleptik bakso yang diberikan bubuk jahe merah (Zingiber officinale var. Rubrum)

\begin{tabular}{lccccc}
\hline & \multicolumn{5}{c}{ Penggunaan jahe merah } \\
\cline { 2 - 6 } Peubah & R0 $(0 \mathrm{~g})$ & $\mathrm{R} 1(1,5 \mathrm{~g})$ & $\mathrm{R} 2(3 \mathrm{~g})$ & $\mathrm{R} 3(4,5 \mathrm{~g})$ & $\mathrm{R} 4(6 \mathrm{~g})$ \\
\cline { 2 - 6 } Warna & $3,30^{\mathrm{a}}$ & $3,40^{\mathrm{a}}$ & $3,57^{\mathrm{a}}$ & $3,53^{\mathrm{a}}$ & $3,37^{\mathrm{a}}$ \\
Aroma & $3,33^{\mathrm{a}}$ & $3,43^{\mathrm{a}}$ & $3,83^{\mathrm{a}}$ & $3,20^{\mathrm{ab}}$ & $3,10^{\mathrm{ab}}$ \\
Rasa & $3,33^{\mathrm{a}}$ & $3,57^{\mathrm{ab}}$ & $4,03^{\mathrm{b}}$ & $3,10^{\mathrm{ac}}$ & $2,93^{\mathrm{ac}}$ \\
Kekenyalan & $3,23^{\mathrm{a}}$ & $3,33^{\mathrm{a}}$ & $3,03^{\mathrm{a}}$ & $3,23^{\mathrm{a}}$ & $3,27^{\mathrm{a}}$ \\
\hline
\end{tabular}

Keterangan : Superskrip yang berbeda pada baris yang sama menunjukkan beda nyata $(\mathrm{P}<0,05)$ 


\section{Aroma}

Hasil pengamatan untuk sifat organoleptik bakso daging kambing terhadap aroma bakso pada Tabel 1 menunjukkan bahwa penilaian panelis berkisar antara 3,33 sampai 3,83 (agak sedap). Terdapat peningkatan penilaian panelis dari $0 \mathrm{~g}$ sampai ke $3 \mathrm{~g}$ kemudian menurun kembali dari 4,5 g sampai ke $6 \mathrm{~g}$.

Analisis ragam menunjukkan bahwa penggunaan bubuk jahe merah berbeda nyata $(\mathrm{P}<0,05)$ terhadap aroma bakso daging kambing. Penggunaan bubuk jahe merah 3 g pada bakso daging kambing adalah level yang diberi nilai tertinggi oleh panelis.

Uji lanjut Aroma dengan Uji Tukey (BNJ) menunjukkan bahwa perlakuan $0 \mathrm{~g}$ tidak berpengaruh nyata $(\mathrm{P}>0,05)$ terhadap $1,5 \mathrm{~g}, 3 \mathrm{~g}, 4,5 \mathrm{~g}$ dan $6 \mathrm{~g}$. Perlakuan 1,5 g tidak berpengaruh nyata $(\mathrm{P}>0,05)$ terhadap $3 \mathrm{~g}, 4,5 \mathrm{~g}$ dan $6 \mathrm{~g}$. Perlakuan $3 \mathrm{~g}$ berpengaruh nyata $(\mathrm{P}<0,05)$ terhadap $4,5 \mathrm{~g}$ dan 6 g. Perlakuan 4,5 g tidak berpengaruh nyata $(\mathrm{P}>0,05)$ terhadap $6 \mathrm{~g}$. Dari analisis data dapat disimpulkan bahwa penggunaan bubuk jahe merah $3 \mathrm{~g}$ adalah level terbaik yang diberi nilai tertinggi oleh panelis. Hal ini disebabkan aroma khas yang dihasilkan oleh kandungan minyak atsiri pada jahe yang menyebabkan bau harum, namun jika bubuk jahe merah yang diberikan levelnya terlalu tinggi maka akan menyebabkan aroma bakso terlalu menusuk di hidung, yang kemudian menyebabkan panelis tidak suka pada bakso tersebut. Menurut Muchtadi dan Sugiono (1992), bahwa produk yang diberi perlakuan pelumuran jahe akan mempengaruhi aroma dari produk tersebut. Aroma harum jahe disebabkan oleh minyak atsiri, sedangkan oleoresin menyebabkan rasa pedas. Komponen utama minyak atsiri jahe yang menyebabkan bau harum adalah zingiberene dan zingiberol (Handrianto, 2016)

\section{Rasa}

Rataan hasil uji organoleptik bakso daging kambing terhadap rasa bakso pada Tabel 1 menunjukkan bahwa penilaian panelis berkisar antara 3,33 (agak enak) sampai 4,03 (enak). Dapat dilihat peningkatan penilaian panelis dari $0 \mathrm{~g}$ sampai ke 3 g kemudian menurun kembali dari 4,5 g sampai ke $6 \mathrm{~g}$.

Hasil analisis ragam menunjukkan bahwa penggunaan bubuk jahe merah berbeda sangat nyata $(\mathrm{P}<0,01)$ terhadap rasa bakso daging kambing. Penggunaan bubuk jahe merah dengan level 3 g pada bakso adalah level yang diberi nilai tertinggi oleh panelis.

Uji lanjut aroma dengan Uji Tukey (BNJ) menunjukkan bahwa perlakuan $0 \mathrm{~g}$ tidak berpengaruh nyata $(\mathrm{P}>0,05)$ terhadap 1,5 g, 4,5 g dan $6 \mathrm{~g}$ tetapi berpengaruh nyata $(\mathrm{P}<0,05)$ terhadap $3 \mathrm{~g}$. Perlakuan 1,5 g tidak 
berpengaruh nyata $(\mathrm{P}>0,05)$ terhadap $3 \mathrm{~g}$ dan 4,5 g akan tetapi berpengaruh nyata $(\mathrm{P}<0,05)$ terhadap $6 \mathrm{~g}$. Perlakuan $3 \mathrm{~g}$ berpengaruh nyata $(\mathrm{P}<0,05)$ terhadap $4,5 \mathrm{~g}$ dan $6 \mathrm{~g}$. Perlakuan $4,5 \mathrm{~g}$ tidak berpengaruh nyata $(\mathrm{P}>0,05)$ terhadap $6 \mathrm{~g}$. Dari analisis data dapat disimpulkan bahwa penggunaan bubuk jahe merah $3 \mathrm{~g}$ adalah level terbaik yang dinilai oleh panelis. Hal ini dikarenakan jahe mempunyai rasa dominan pedas yang disebabkan oleh oleoresin dan senyawa turunan terpenoid pada jahe seperti Seskuiterpen Zingiberene juga memberikan kontribusi sensori berupa rasa hangat, namun jika bubuk jahe merah yang diberikan levelnya terlalu tinggi maka akan menyebabkan rasa bakso terlalu pedas dan pahit yang kemudian tidak disukai panelis. Ibrahim et al. (2015) menyatakan oleoresin jahe banyak mengandung komponen pembentuk rasa pedas dan pahit yang tidak mudah menguap (non volatile oil). Komponen oleoresin jahe teridiri atas gingerol, zingiberen, shaogol, minyak atsiri dan resin.

\section{Kekenyalan}

Hasil pengamatan untuk sifat organoleptik bakso daging kambing terhadap kekenyalan bakso pada Tabel 1 menunjukkan bahwa penilaian panelis berkisar antara 3,23 sampai 3,33 (agak kenyal). Dapat dilihat bahwa penilaian panelis meningkat dari $0 \mathrm{~g}$ sampai $1,5 \mathrm{~g}$ kemudian menurun dari $1,5 \mathrm{~g}$ ke $3 \mathrm{~g}$ lalu meningkat kembali dari 3g sampai ke $6 \mathrm{~g}$.

Analisis ragam menunjukkan bahwa penggunaan bubuk jahe merah tidak berbeda nyata $(\mathrm{P}>0,05)$ terhadap kekenyalan pada bakso daging kambing. Bubuk jahe merah yang digunakan pada bakso sampai dengan level $6 \mathrm{~g}$ tidak dapat mempengaruhi tingkat kekenyalan pada bakso. Hal ini disebabkan karena kandungan kimia dalam rimpang jahe seperti enzim proteolitik dapat menyebabkan daging menjadi lunak dan tidak kenyal. Sama seperti yang diungkapkan Muchtadi dan Sugiono (1992), bahwa enzim proteolitik dalam jahe dapat dimanfaatkan untuk melunakkan daging sebelum dimasak. Besar kecilnya nilai kekenyalan bakso juga dapat dipengaruhi oleh beberapa faktor, diantaranya adanya bahan pengisi yang digunakan, kemudian jenis atau bagian daging yang digunakan juga berpengaruh terhadap kekenyalan (Kusnadi et al., 2012).

\section{KESIMPULAN}

Dari hasil penelitian dan pembahasan semua variabel dapat disimpulkan bahwa, penggunaan bubuk jahe merah dengan level 3 g mempengaruhi sifat organoleptik pada variabel aroma dan rasa, sedangkan untuk warna dan kekenyalan, bubuk jahe merah yang digunakan sampai dengan level $6 \mathrm{~g}$ 
tidak mempengaruhi sifat organoleptik bakso daging kambing. Penggunaan bubuk jahe merah level $3 \mathrm{~g}$ dapat memberikan tingkat penerimaan terhadap sifat organoleptik bakso daging kambing.

\section{DAFTAR PUSTAKA}

Handrianto P. 2016. Uji antibakteri ekstrak jahe merah Zingiber officinale var. Rubrum terhadap Staphylococcus aureus dan Escherichia coli. Journal of Research and Technologies 2(1):24.

Ibrahim, M. A., Yunianta, dan Feronika. 2016. Pengaruh suhu dan lama waktu ekstraksi terhadap sifat kimia dan fisik pada pembuatan minuman sari jahe merah (Zingiber officinale var. Rubrum) dengan kombinasi penambahan madu sebagai pemanis. Jurnal Pangan dan Agroindustri 3(2):530-541.

Kusnadi, D.C., V. P. Bintoro, dan A. N. AlBaarri. 2012. Tingkat kekenyalan dan kadar protein pada bakso kombinasi daging sapi dan daging kelinci. Jurnal
Aplikasi Teknologi Pangan (1)2:2831.

Muchtadi, T. R., dan Sugiono. 1992. Ilmu Pengetahuan Bahan Pangan. Departemen Pendidikan dan Kebudayaan. Buku. Direktorat Jendral Pendidikan Tinggi. Pusat Antar Universitas Pangan dan Gizi, Institut Pertanian Bogor, Bogor.

Panjaitan E. N., S. Awaluddin, dan P. Djendakita. 2012. Formulasi gel dari ekstrak rimpang jahe merah (Zingiber officinale var. Rubrum). Journal of Pharmaceutics and Pharmacology 1(1): 9-20.

Soekarto. T. S. 1985. Penilaian Organoleptik untuk Industri Pangan dan Hasil Peternakan. Bhratara Karya Aksara. Jakarta.

Steel, R. G. D. dan J. H. Torrie. 1993. Prinsip dan Prosedur Statistika (Pendekatan Biometrik) Penerjemah B. Sumantri. Gramedia Pustaka Utama, Jakarta.

Tiven, N. C., E. Suryanto, dan Rusman. 2007. Komposisi kimia, sifat fisik dan organoleptik bakso daging kambing dengan bahan pengeyal yang berbeda. Jurnal Agritech 27(1):1-6. 